\title{
EGFR NM_005228.3:c.2290_2291ins12
}

National Cancer Institute

\section{Source}

National Cancer Institute. EGFR NM 005228.3:C.2290 2291ins12. NCI Thesaurus. Code C98612.

An insertion of 12 nucleotides, TCCAGGAAGCCT, between position 2302 and 2303 of the coding sequence of the EGFR gene. 